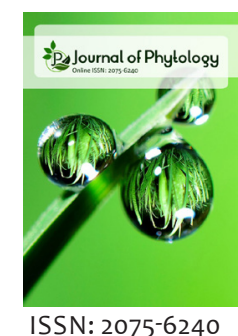

Received: July 14, 2021 Revised: October 26, 2021 Accepted: October 28, 2021 Published: November 10, 2021

*Corresponding author: M. K. Kalarani

kalarani.mk@tnau.ac.in

\section{Assessing antioxidant system and yield of maize (Zea mays L.) inbreds under elevated temperature condition}

\author{
L. Priyanandhini', M. K. Kalarani' ${ }^{1 *}$, A. Senthil', N. Senthil'2, K. Anitha', \\ M. Sai Venkata Ravi Teja'
}

'Department of Crop Physiology, Tamil Nadu Agricultural University, Coimbatore- 641003, Tamil Nadu, India, ${ }^{2}$ Department of Plant Molecular Biology and Bioinformatics, Tamil Nadu Agricultural University, Coimbatore- 641003, Tamil Nadu, India

\begin{abstract}
Maize (Zea mays L.) is the most important food and feed crop grown under diverse soil and climatic conditions. Among the cereals, demand for maize is increasing year after year, but fluctuation in climatic conditions especially the temperature extremes is the current and future threat in maize cultivation. Each degree Celsius increase in global mean temperature causes yield reduction up to 7.4 per cent in maize. The high temperature stress impact at the reproductive stage affects grain filling rate and duration. Adaptation of maize crop to future warmer climatic conditions requires a better understanding of physiological responses to elevated temperatures. With this view, a pot culture experiment was conducted at the Department of Crop Physiology, TNAU, Coimbatore during the summer season of 2020. Two maize inbreds viz., UMI 1230 and CBM-DL- 322 were taken for the study and exposed to high temperature stress treatments viz., $\mathrm{T}_{1}$ - ambient, $\mathrm{T}_{2}$ - ambient $+4^{\circ} \mathrm{C}$ and $\mathrm{T}_{3}$ - ambient $+6^{\circ} \mathrm{C}\left(44^{\circ} \mathrm{C}\right)$ for 10 days during the reproductive stage to assess the changes in biochemical and yield traits. The ambient $+4^{\circ} \mathrm{C}$ treatment revealed that the maize inbred line CBM-DL-322 recorded lower malondialdehyde content with over production of antioxidant enzyme activity (superoxide dismutase, catalase and ascorbate peroxidase). Cob weight and seed set parentage showed a negative correlation with both elevated temperatures. It is concluded that the maize inbreds line CBM-DL- 322 performed better at an elevated temperature at ambient $+4^{\circ} \mathrm{C}$ and recorded more cob weight $(57.09 \mathrm{~g})$ compared to UMI 1230 inbred $(43.56 \mathrm{~g})$.
\end{abstract}

Keywords: Maize, high temperature, antioxidant enzyme activity, yield.

\section{INTRODUCTION}

Global climate change leads to adverse effects on agricultural productivity. Among the climate variables, temperature extremes severely affect crop yields when occur during the reproductive stage. Each of the last four decades has been warmer than the previous decade since 1850 . According to the IPCC - 2018, if current rates of global warming continue, global temperatures will rise by 1.5 degrees Celsius between 2030 and 2052. Mikhaylov et al. (2020) reported that in the last 100 years, the earth's global temperature has increased by 0.5-1 degrees Celsius. According to Raza et al. (2019), over the last few centuries, changes in climatic conditions such as temperature and rainfall patterns had a significant impact on the morphology and physiology of a wide range of crop species and so it can generate excess energy in high temperatures, but a larger increase in temperature reduces plant growth and photosynthesis rate.
Maize (Zea mays L.) is the thermophilic $\mathrm{C}_{4}$ plant (Cabral et al., 2017) and one of the world's most important food staples and widely planted cereal (Tesfaye et al., 2017). In India, after rice and wheat, maize is considered as a third important cereal crop grown in a wide range of soil and climatic conditions. According to the Indian maize scenario-2021, in India during 2018-19, maize is cultivated in an area of around 9.2 million ha and the production was 27.8 million MT in 2018-19. Fluctuation in temperature leads to changes in physiology and biochemical aspects of a cell organelle, which accordingly affect the growth and development of maize plants (Sita et al., 2017). The sub-optimal and supra-optimal temperatures have the greatest impact on the reproductive stage of the maize plant (Waqas et al., 2021). Variations in temperature cause cellular membranes damage, prevent nutrient absorption and decrease the activity of many enzymes involved in various metabolic processes of the maize plants (Hussain et al., 2019).

The cell membrane is considered as an important component of cells in the plant and its stability is affected by high temperature,

Copyright: () The authors. This article is open access and licensed under the terms of the Creative Commons Attribution License (http://creativecommons.org/licenses/by/4.0/) which permits unrestricted, use, distribution and reproduction in any medium, or format for any purpose, even commercially provided the work is properly cited. Attribution - You must give appropriate credit, provide a link to the license, and indicate if changes were made. 
due to which leakage of ions from the cells takes place. Plants protect themselves against oxidative stress by enhancing the antioxidant defense enzymes such as superoxide dismutase (SOD), catalase (CAT), ascorbate peroxidase (APX) to scavenge the reactive oxygen species as a consequence of elevated temperatures (Dwivedi et al., 2019). But, the severity of heat stress creates an imbalance between the reactive oxygen species and the antioxidant scavenging system in the cell (Zhu et al., 2010). Thus, membrane stability is affected by various activated oxygen species (AOS) like superoxide anion radical $\left(\mathrm{O}_{2}\right)$, hydroxyl radicals $(\mathrm{OH})$ and hydrogen peroxide $\left(\mathrm{H}_{2} \mathrm{O}_{2}\right)$ molecules which are produced under high temperature stress (Yuzbasioglu et al., 2017). In maize, at reproductive stage (silking stage), the potential number and size of kernels are defined and grain filling occurs until physiological maturity when the final crop yield is determined. Two weeks before and after silking is a critical period for maize to produce a higher yield. The occurrence of any abiotic and biotic stress during this critical period registers a significant negative impact on yield. Hence, this study was proposed to understand and quantify the impact of elevated temperatures occuring during the reproductive stage on the biochemical and yield traits of selected maize inbreds. In this study, changes in lipid peroxidation (MDA) and antioxidant enzymes activity, cob weight and seed set percentage of yield attributes in maize under elevated temperatures were observed and discussed.

\section{MATERIAL AND METHODS}

\section{Preparation of Plant Material}

Pot culture experiment was carried out during the summer of 2020, at the Department of Crop Physiology, Tamil Nadu Agricultural University, Coimbatore. Pots with a size of $32 \mathrm{~cm}$ (diameter) were filled with red soil, clay soil, and vermicompost in a ratio of 2:1:1 for sowing the seeds of maize inbreds (UMI 1230 and CBM-DL-322). Two plants per pot were maintained following a factorial completely randomized design with seven replications. All the recommended practices were followed based on the TNAU crop production guide, to maintain a healthy crop.

\section{Imposition of High Temperature Stress}

The plants were grown in a natural environment until they reached the reproductive stage. At the reproductive stage (52 DAE), maize plants were transferred to a growth chamber (Open Top Chamber-OTC) where the high temperature stress was imposed for 10 days in a closed environment. In the control chamber, the ambient temperature was maintained at $37^{\circ} \mathrm{C}$ while in OTC, one chamber was maintained at $37^{\circ} \mathrm{C}$ (ambient) plus $4^{\circ} \mathrm{C}$ and the other at $37^{\circ} \mathrm{C}$ plus $6^{\circ} \mathrm{C}$. Ten days after the treatment, the stressed plants were moved from the growth chamber to the ambient environment to recover.The observations were taken during stress period at reproductive stage (52 DAE) and plant samples were collected for analysis from each replication and mean values were computed.

\section{Analysis of Antioxidant System}

With slight changes to the technique of measurement, the level of lipid peroxidation in the leaf tissue was quantified in terms of malondialdehyde concentration determined by the TBA reaction (Hodges et al.,1999). The amount of super oxide dismutase in the leaf sample was measured using the nitroblue tetrazolium (NBT) method outlined by Beauchamp and Fridovich (1971). The activity of ascorbate peroxidase in the leaves was determined using the method of Elavarthi and Martin (2010). Catalase (CAT) activity was assessed as the rate of reduction in hydrogen peroxide and absorbance was taken at $240 \mathrm{~nm}$ as suggested Aebi and Bergmeyer (1983).

\section{Yield Parameters}

Finally for yield attributes of cob weight (selected cobs were dried to a moisture content of $12 \%$, weighed and the mean weight was expressed in $\mathrm{g}$ ) and seed set percentage (seed set percentage $=$ filled $/($ filled + half filled + unfilled $) * 100 \%)$ were determined as described by Prasad et al., (2006). The grains from the sun dried cobs were separated and the average grain weight per plant was expressed in gram per plant.

\section{Statistical Analysis}

IBM SPSS Statistics version 23.0 software (http://www.spss. com) was used for statistical analysis. The mean values of each character were examined using analysis of variance to determine their significance.

\section{RESULTS}

\section{Malondialdehyde Content}

From the data (Figure 1), it was observed that the UMI 1230 inbred $\left(0.78 \mu \mathrm{mol} \mathrm{g}^{-1}\right.$ of fresh weight $)$ produced significantly higher MDA compared to CBM-DL-322 inbred $\left(0.26 \mu \mathrm{mol} \mathrm{g} \mathrm{g}^{-1}\right.$ of fresh weight). Among different high temperature treatments, ambient $+6^{\circ} \mathrm{C}\left(0.70 \mu \mathrm{mol} \mathrm{g}{ }^{-1}\right.$ of fresh weight) produced significantly higher MDA compared to the other treatments. The interaction effect between genotype and temperature treatments showed that CBM-DL-322 inbred $\left(0.19 \mu \mathrm{mol} \mathrm{g}^{-1}\right.$ of fresh weight) under ambient conditions produced significantly lower MDA content compared to all other remaining combinations. The inbred UMI 1230 grown under ambient $+6^{\circ} \mathrm{C}\left(1.06 \mu \mathrm{mol} \mathrm{g}{ }^{-1}\right.$ of fresh weight $)$ produced significantly higher MDA content compared to ambient and ambient $+4^{\circ} \mathrm{C}$ treatments.

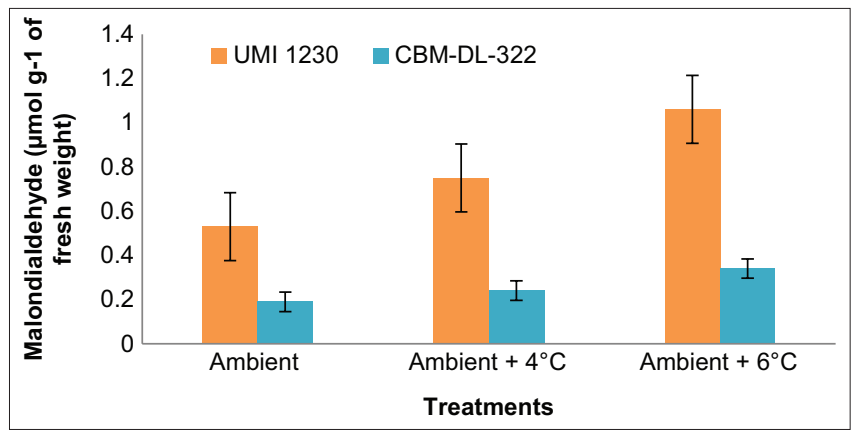

Figure 1: Effect of elevated temperature stress on malondialdehyde content in maize leaves at reproductive stage 


\section{Superoxide Dismutase Activity}

From Figure 2, it was observed that there was an enhanced production of superoxide dismutase in CBM-DL-322 $(1.18 \mathrm{mg}$ protein $\left.^{-1} \mathrm{~min}^{-1}\right)$ than the UMI $1230\left(1.02 \mathrm{mg}\right.$ protein $\left.{ }^{-1} \mathrm{~min}^{1}\right)$ under elevated temperature conditions. Both the inbred lines which were exposed to ambient $+6^{\circ} \mathrm{C}\left(1.25 \mathrm{mg}\right.$ protein $\left.{ }^{-1} \mathrm{~min}^{-1}\right)$ recorded a significant increase in the activity of SOD compared to the other temperature treatments. In both temperature treatments i.e., ambient $+4^{\circ} \mathrm{C}$ and ambient $+6^{\circ} \mathrm{C}$, the inbred CBMDL-322 inbred line recorded significantly higher SOD activity compared to UMI 1230. The interaction effect also showed that the inbred line CBM-DL-322 grown under ambient $+6^{\circ} \mathrm{C}$ condition recorded significantly higher SOD activity $(1.35 \mathrm{mg}$ protein $^{-1} \min ^{1}$ ) compared to all other combinations.

\section{Ascorbate Peroxidase Activity}

From Table 1, it was observed that the maize inbred lines exposed to ambient $+6^{\circ} \mathrm{C}$ temperature (43.51 change in OD at $430 \mathrm{~nm} \mathrm{~g}^{-1}$ ) and ambient $+4^{\circ} \mathrm{C}$ temperature (41.93 change in OD at $430 \mathrm{~nm} \mathrm{~g}^{-1}$ ) recorded significantly higher APX activity compared to the lines grown under ambient conditions. Among the maize inbreds, CBM-DL-322 registered the highest APX activity at ambient $+4^{\circ} \mathrm{C}\left(44.05\right.$ change in $\mathrm{OD}$ at $\left.430 \mathrm{~nm} \mathrm{~g}^{-1}\right)$ and at ambient $+6^{\circ} \mathrm{C}\left(46.49\right.$ change in $\mathrm{OD}$ at $\left.430 \mathrm{~nm} \mathrm{~g}^{-1}\right)$. The interaction between genotype and treatments showed that the inbred line CBM-DL-322 grown under elevated temperature conditions recorded significantly higher APX activity compared to all other combinations.

\section{Catalase Activity}

Table 2 revealed that the maize inbred CBM-DL-322 recorded significantly higher catalase activity (101.11 unit $\mathrm{g}^{-1} \mathrm{~min}^{-1}$ ) compared to UMI 1230 (95.49 unit $\left.\mathrm{g}^{-1} \mathrm{~min}^{-1}\right)$. Irrespective of genotypes, under ambient $+6^{\circ} \mathrm{C}$ maize plants showed significantly higher CAT activity $\left(104.02 \mu \mathrm{mol} \mathrm{g}^{-1}\right.$ of fresh weight) compared to the other treatments.

\section{Cob Weight}

The results (Figure 3) revealed that the maize inbred CBM-DL-322 recorded significantly higher cob weight (56.67g) compared to UMI $1230(43.1 \mathrm{lg})$ under elevated temperature conditions. But irrespective of genotypes, the maize plants grown under ambient temperature registered significantly increased cob weight $(63.80 \mathrm{~g})$ compared to the maize plants grown under elevated temperatures. Also, it was observed that the inbreds grown at ambient $+4^{\circ} \mathrm{C}(50.33 \mathrm{~g})$ were observed with significantly higher cob weight compared to the inbreds grown at ambient $+6^{\circ} \mathrm{C}$ temperature $(35.54 \mathrm{~g})$.

\section{Seed Set Percentage}

It was observed that the maize inbred CBM-DL-322 registered a significantly higher mean seed set percentage of $72.99 \%$ compared to UMI 1230 line (61.07\%). Also this study revealed

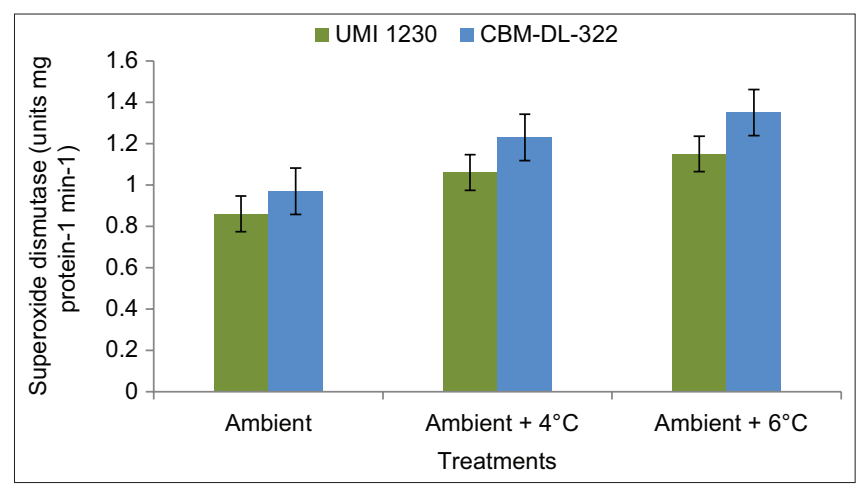

Figure 2: Effect of elevated temperature stress on SOD activity in maize leaves at reproductive stage

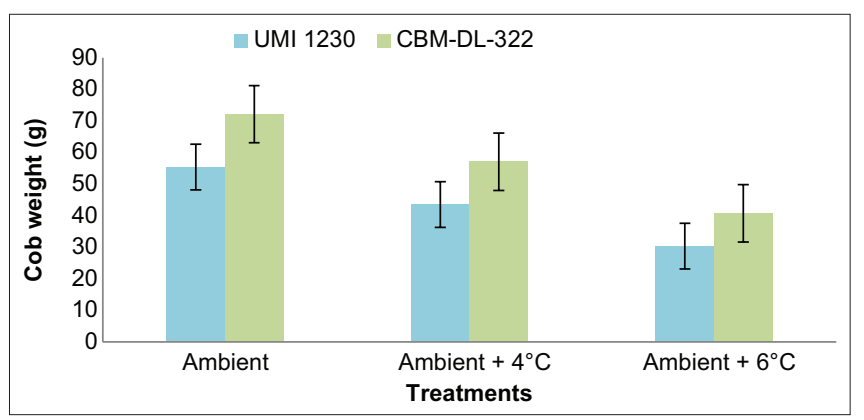

Figure 3: Effect of elevated temperature stress on cob weight $(\mathrm{g})$ in maize inbreds

Table 1: Effect of elevated temperature stress on ascorbate peroxidase (APX) activity in maize leaves at reproductive stage

\begin{tabular}{|c|c|c|c|}
\hline \multirow{2}{*}{$\begin{array}{l}\text { Treatments/ } \\
\text { Genotypes }\end{array}$} & \multicolumn{3}{|c|}{ Ascorbate peroxidase (change in 0D at $430 \mathrm{~nm} \mathrm{~g}^{-1}$ ) } \\
\hline & UMI 1230 & CBM-DL-322 & $\begin{array}{l}\text { Temperature } \\
\text { Mean }\end{array}$ \\
\hline Ambient $\left(37^{\circ} \mathrm{C}\right)$ & 36.25 & 37.46 & 36.86 \\
\hline Ambient $+4{ }^{\circ} \mathrm{C}$ & 39.80 & 44.05 & 41.93 \\
\hline Ambient $+6{ }^{\circ} \mathrm{C}$ & 40.52 & 46.49 & 43.51 \\
\hline \multirow[t]{2}{*}{ Genotype Mean } & 38.86 & 42.67 & \\
\hline & Genotype & Treatment & Interaction \\
\hline $\mathrm{CD}$ & 1.401 & 1.716 & 2.426 \\
\hline SEm & 0.486 & 0.596 & 0.843 \\
\hline
\end{tabular}

Table 2: Effect of elevated temperature stress on catalase (CAT) activity in maize leaves at reproductive stage

\begin{tabular}{lccc}
\hline Treatments & \multicolumn{3}{c}{ Catalase (unit $\mathrm{g}^{-1} \mathrm{~min}^{-1}$ ) } \\
\cline { 2 - 4 } Genotypes & UMI 1230 & CBM-DL-322 & Temperature Mean \\
\hline Ambient $\left(37^{\circ} \mathrm{C}\right)$ & 88.85 & 91.28 & 90.07 \\
Ambient $+4^{\circ} \mathrm{C}$ & 97.03 & 104.60 & 100.82 \\
Ambient $+6^{\circ} \mathrm{C}$ & 100.58 & 107.45 & 104.02 \\
Genotype Mean & 95.49 & 101.11 & \\
\hline & Genotype & Treatment & Interaction \\
\hline CD & 3.373 & 4.131 & NS \\
SEm & 1.171 & 1.434 & 2.029 \\
\hline
\end{tabular}

that the maize inbreds grown under ambient $+4^{\circ} \mathrm{C}$ temperature (66.54\%) recorded significantly higher seed set percentage compared to the inbreds grown under ambient $+6^{\circ} \mathrm{C}$ condition (44.65\%). Under ambient $+4^{\circ} \mathrm{C}$, the inbred CBM-DL-322 showed a significantly higher seed set percentage (77.82\%) 
than the UMI 1230 (55.25\%). But, under ambient+6C, CBMDL-322 inbred line $(49.40 \%)$ does not differ significantly with UMI 1230 line (55.25\%) (Figure 4).

\section{DISCUSSION}

\section{Malondialdehyde Content}

Malondialdehyde, a product of peroxidation of unsaturated fatty acids, was used as a diagnostic tool for free radical damage to the cell membrane (Tommasino et al., 2012). According to Stark (2005), MDA content contributes to the loss of cellular activities by inactivating membrane enzymes and even cytoplasmic proteins through the formation of ROS. The data obtained from this experiment was found in accordance with the findings of Jincy et al. (2019). MDA content produced under ambient $+6^{\circ} \mathrm{C}$ conditions was found to be significantly higher compared to remaining conditions.

Reactive oxygen species like superoxide radicals could induce membrane lipid peroxidation which leads to loss of membrane stability and produce MDA as a byproduct and this may be the reason for higher MDA content observed in UMI 1230 inbred line exposed to high temperature stresses such as ambient temperature $+4^{\circ} \mathrm{C}$ and $6^{\circ} \mathrm{C}$. However, among two inbred lines, CBM-DL-322 recorded reduced MDA content compared to the UMI 1230 in both elevated temperature treatments which indicates that at the cellular level CBM-DL-322 maize inbred line is better managed with an efficient free radical quenching system that offers protection against oxidative stress due to high temperatures (Yadav et al., 2018).

\section{Effect of High Temperature on Antioxidant Enzyme Activity}

Plants use complex antioxidant defense systems to combat uncontrolled ROS production and protect themselves from oxidative damage. Under stressful conditions, all plant species require a balance between ROS production and antioxidant enzyme activity (Tesfaye et al., 2018). Enzymatic antioxidants protect the plant cells from the oxidative damage caused by abiotic stresses through detoxification of ROS.

Against reactive oxygen species, plants have an enzymatic antioxidant defense system. SOD is the first line of defense in

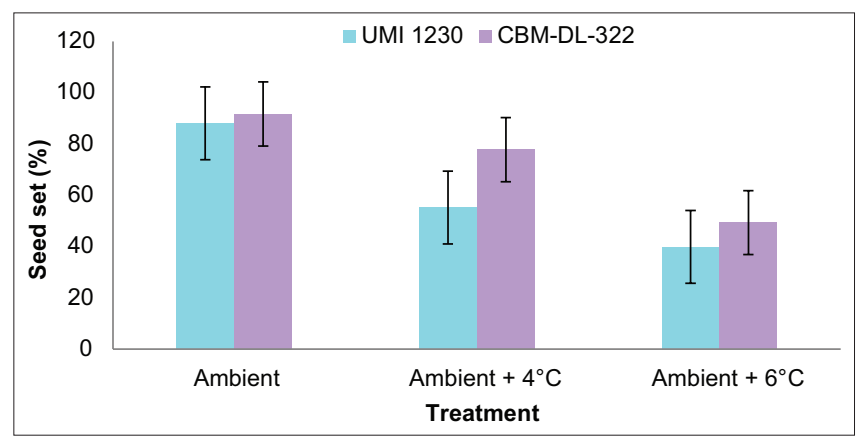

Figure 4: Effect of elevated temperature stress on seed set percentage in maize inbreds such antioxidant system, catalysing the dismutation of $\mathrm{O}_{2}$ - to $\mathrm{H}_{2} \mathrm{O}_{2}$ and $\mathrm{O}_{2}$. Gill and Tuteja (2010) reported that when plants were subjected to high temperature stress, the equilibrium between the production and scavenging of reactive oxygen species was disrupted, causing oxidative damage to cell membranes. Singh et al. (2020) reported that the activity of SOD in maize was significantly increased under elevated temperature conditions. In the present study also it was observed that under ambient temperature $+4^{\circ} \mathrm{C}$ condition, SOD activity was found to be significantly increased in both UMI 1230 and CBM-DL-322 maize inbred lines. Due to the effective activation of the antioxidant machinery, the plants under oxidative stress could manage the stress effectively and avoid cell membrane damage and protein degradation. These findings were in accordance with Khayatnezhad and Gholamin (2021) that the synthesis of SOD is part of the plant's defensive mechanism against oxidative stress in moderately and highly tolerant plants under abiotic stress conditions.

The ascorbate-glutathione cycle is the main hydrogen peroxide detoxification system in plant chloroplasts. Ascorbate peroxidase uses ascorbic acid as a specific electron donor to reduce $\mathrm{H}_{2} \mathrm{O}_{2}$ to water. Caverzan et al. (2012) reported that the role of APX is not only limited to the chloroplast, it also occurs in the cytosol, mitochondria and peroxisome. Under high temperature conditions, ascorbic acid content was increased when compared to non-stressed plants (Xiang et al., 2019). Similar result was also observed in this study in maize inbred lines under elevated temperature conditions. The APX enzyme is involved in hydrogen peroxide scavenging and its activity has been correlated with the relative tolerance of the crop (Sairam et al., 1997). In current study, both maize inbred lines UMI 1230 and CBM-DL-322 recorded higher APX enzyme activity compared to ambient condition but among the inbreds, CBM-DL-322 registered the highest activity which indicates its relative ability to tolerate the temperature induced oxidative stress compared to UMI 1230. The increased activity of APX enzyme may be due to nonspecific plant defense responses under temperature stress. Zhu et al., (2010) and Yuzbasioglu et al. (2017) reported that the ascorbate peroxidase activity was increased in maize seedlings when the temperature was increased from the ambient condition.

Catalase protects the cell from oxidative damage caused by reactive oxygen species by catalyzing the breakdown of $\mathrm{H}_{2} \mathrm{O}_{2}$ into water and oxygen. In rice, Zafar et al. (2020) reported that catalase activity was doubled under elevated temperature stress. In the present study, also catalase activity increased under elevated temperature conditions in both the inbreds - UMI 1230 and CBM-DL-322 - compared to the ambient condition. Specifically, the maize inbred CBM-DL-322 registered a significant increase in CAT activity over the inbred CBM-DL-322 which indicates its potential defense against oxidative damage.

\section{Effect of High Temperature Stress on Yield Parameters}

\section{Cob weight}

Regarding the cob weight, the findings were in agreement with the results of Shim et al., (2017) who reported that the weight of cob 


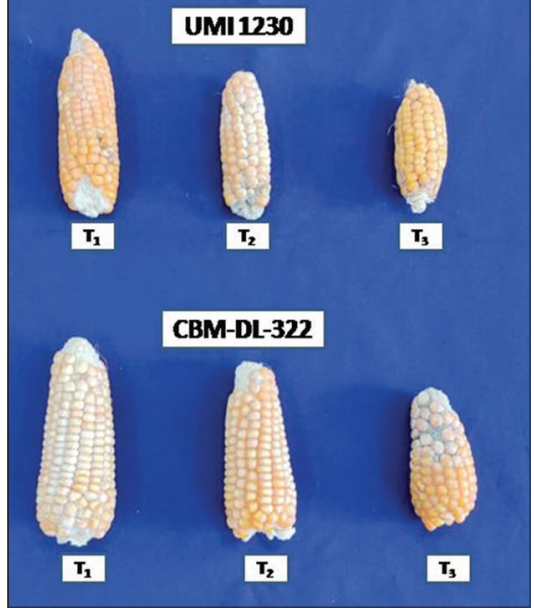

Figure 5: Cob/ear length of maize inbreds subjected to elevated temperature condition. (Treatments: $T_{1}-$ ambient (control), $\mathrm{T}_{2}$-ambient+4 ${ }^{\circ} \mathrm{C}, \mathrm{T}_{3}$-ambient $\left.+6^{\circ} \mathrm{C}\right)$

gets decreased in maize plants exposed to elevated temperatures during the reproductive stage. It may be due to increased lipid peroxidation (accumulation of MDA) which leads to the damage of cell membrane preceded by a reduction in photosynthetic rate and yield and quality of the grains in maize (Suwa et al., 2010). However, increased accumulation of antioxidants in some of the genotypes resulting in a reduced level of membrane damage and further maintenance of normal photosynthesis under heat stress leads to increase in cob weight (Hasanuzzaman et al., 2013). This is in accordance with the results of the present study in which CBM-DL-322 performed better at elevated temperature of plus $4^{\circ} \mathrm{C}$ among the two maize inbred lines.

\section{Seed set percentage}

From the results, it was observed that the seed setting percentage was reduced significantly by 15 and $54 \%$ when plants were exposed to the elevated temperatures of about 41 and $44^{\circ} \mathrm{C}$, respectively during the reproductive stage (Figure 5). The reduction in seed set percentage was the consequence of disruption in source-sink relations by reducing the source capacity and sink formation as a feedback mechanism under elevated temperature stress conditions (Lamichaney et al., 2021). Devasirvatham et al., (2012) reported in chickpea that reduction in the pollen formation and its viability causes lower seed setting under high-temperature. However, among two inbred lines, CBM-DL-322 recorded a lesser reduction in seed set percentage compared to the UMI 1230 in both the elevated temperature treatments which indicates the ability of the inbred CBM-DL-322 to perform better under such high temperature conditions due to its inherent capacity to activate the antioxidant system to nullify the effects of reactive oxygen species and by the way better performance interms of photosynthesis, partitioning of assimilates and yield.

\section{CONCLUSION}

During heat stress, ROS are produced in plants and cause membrane oxidation resulting in organelle degradation and cell death. The present study revealed that the elevated temperatures beyond optimum showed a negative impact on cob weight and seed set percentage. This is due to the changes in membrane orientation in cell organelles such as chloroplast etc., which lead to a reduction in source capacity and sink formation and also pollen and its viability under elevated temperature condition. Further, it was observed a significant enhancement in antioxidant enzymes activities in the maize inbred CBM-DL-322 probably detoxified the ROS effectively compared to the UMI 1230 and hence, CBM-DL-322 managed to withstand under elevated temperatures and sustained the yield.

\section{ACKNOWLEDGEMENT}

The authors are thankful to the Department of Crop Physiology and Department of Biotechnology for providing the OTC facility and maize inbred seeds, respectively.

\section{REFERENCES}

Aebi, H. E., \& Bergmeyer, H. U. (1983). Methods of Enzymatic Analysis, 3, Verlag Chemic, Deerfield Beach, FL. p273-286.

Beauchamp, C., \& Fridovich, I. (1971). Superoxide dismutase: Improved assays and an assay applicable to acrylamide gels. Analytical Biochemistry, 44(1), 276-287. https://doi.org/10.1016/00032697(71)90370-8

Caverzan, A., Passaia, G., Rosa, S. B., Ribeiro, C. W., Lazzarotto, F., \& Margis-Pinheiro, M. (2012). Plant responses to stresses: Role of ascorbate peroxidase in the antioxidant protection. Genetics and Molecular Biology, 35(4), 1011-1019. https://doi.org/10.1590/s141547572012000600016

Devasirvatham, V., Tan, D. K. Y., Gaur, P. M., Raju, T. N., \& Trethowan, R. M. (2012). High temperature tolerance in chickpea and its implications for plant improvement. Crop and Pasture Science, 63(5), 419-428. https://doi.org/10.1071/CP11218

Dwivedi, S. K., Basu, S., Kumar, S., Kumari, S., Kumar, A., Jha, S., \& Kumar, G. (2019). Enhanced antioxidant enzyme activities in developing anther contributes to heat stress alleviation and sustains grain yield in wheat. Functional Plant Biology, 46(12), 1090-1102. https://doi.org/10.1071/ FP19016

Ebi, K. L., Anderson, C. L., Hess, J. J., Kim, S. H., Loladze, I., Neumann, R. B., \& Wood, R. (2021). Nutritional quality of crops in a high $\mathrm{CO}_{2}$ world: An agenda for research and technology development. Environmental Research Letters, 16(6), 064045.

Elavarthi, S., \& Martin, B. (2010). Spectrophotometric assays for antioxidant enzymes in plants. In Plant Stress Tolerance Humana Press, 273-280. https://doi.org/10.1007/978-1-60761-702-0_16

Gill, S. S., \& Tuteja, N. (2010). Reactive oxygen species and antioxidant machinery in abiotic stress tolerance in crop plants. Plant Physiology Biochemistry, 48, 909-930. https://doi.org/10.1016/j. plaphy.2010.08.016

Hasanuzzaman, M., Nahar, K., Alam, M., Roychowdhury, R., \& Fujita, M. (2013). Physiological, biochemical, and molecular mechanisms of heat stress tolerance in plants. International Journal of Molecular Sciences, 14(5), 9643-9684. https://doi.org/10.3390/ijms14059643

Hodges, D. M., DeLong, J. M., Forney, C. F., \& Prange, R. K. (1999). Improving the thiobarbituric acid-reactive-substances assay for estimating lipid peroxidation in plant tissues containing anthocyanin and other interfering compounds. Planta, 207(4), 604-611. https://doi. org/10.1007/s004250050524

Hussain, H. A., Men, S., Hussain, S., Chen, Y., Ali, S., Zhang, S., \& Wang, L. (2019). Interactive effects of drought and heat stresses on morphophysiological attributes, yield, nutrient uptake and oxidative status in maize hybrids. Scientific Reports, 9(1), 1-12. https://doi.org/10.1038/ s41598-019-40362-7

Jincy, M., Jeyakumar, P., Boominathan, P., Manivannan, N., Varanavasiappan, S., \& Prasad, V. B. R. (2019). Impact of drought and high temperature stress on oxidants and antioxidants in green gram (Vigna radiata (L.) Wilczek). Journal of Pharmacognosy and 
Phytochemistry, 8(3), 1809-1813.

Khayatnezhad, M., \& Gholamin, R. (2021). The effect of drought stress on the superoxide dismutase and chlorophyll content in durum wheat genotypes. Advancements in Life Sciences, 8(2), 119-123.

Lamichaney, A., Parihar, A. K., Hazra, K. K., Dixit, G. P., Katiyar, P. K., Singh, D. \& Singh, N. P. (2021). Untangling the Influence of Heat Stress on Crop Phenology, Seed Set, Seed Weight, and Germination in Field Pea (Pisum sativum L.). Frontiers in Plant Science, 12, 437. https://doi. org/10.3389/fpls.2021.635868

Mikhaylov, A., Moiseev, N., Aleshin, K., \& Burkhardt, T. (2020). Global climate change and greenhouse effect. Entrepreneurship and Sustainability Issues, 7(4), 2897. http://doi.org/10.9770/jesi.2020.7.4(21)

Prasad, P. V. V., Boote, K. J., Allen Jr, L. H., Sheehy, J. E., \& Thomas, J. M. G. 2006. Species, ecotype and cultivar differences in spikelet fertility and harvest index of rice in response to high temperature stress. Field Crops Research, 95(2-3), 398-411. https://doi.org/10.1016/j. fcr.2005.04.008

Ramirez-Cabral, N. Y., Kumar, L., \& Shabani, F. (2017). Global alterations in areas of suitability for maize production from climate change and using a mechanistic species distribution model (CLIMEX). Scientific Reports, 7(1), 1-13. https://doi.org/10.1038/s41598-017-05804-0

Raza, A., Razzaq, A., Mehmood, S. S., Zou, X., Zhang, X., Lv, Y., \& Xu, J. (2019). Impact of climate change on crops adaptation and strategies to tackle its outcome: A review. Plants, 8(2), 34. https://doi. org/10.3390/plants8020034

Sairam, R. K., Srivastava, G. C., \& Saxena, D. C. (2000). Increased antioxidant activity under elevated temperatures: A mechanism of heat stress tolerance in wheat genotypes. Biologia Plantarum, 43(2), 245-251. https://doi.org/10.1023/A:1002756311146

Shim, D., Lee, K. J., \& Lee, B. W. (2017). Response of phenology-and yield-related traits of maize to elevated temperature in a temperate region. The Crop Journal, 5(4), 305-316. https://doi.org/10.1016/j. cj.2017.01.004

Singh, I., Debnath, S., Gautam, A., \& Yadava, P. (2020). Characterization of contrasting genotypes reveals general physiological and molecular mechanisms of heat-stress adaptation in maize (Zea mays L.). Physiology and Molecular Biology of Plants, 26(5), 921-929. https:// doi.org/10.1007/s12298-020-00801-6

Sita, K., Sehgal, A., HanumanthaRao, B., Nair, R. M., Vara Prasad, P. V., Kumar, S., \& Nayyar, H. (2017). Food legumes and rising temperatures: Effects, adaptive functional mechanisms specific to reproductive growth stage and strategies to improve heat tolerance. Frontiers in Plant Science, 8, 1658. https://doi.org/10.3389/fpls.2017.01658

Stark G. (2005). Functional consequences of oxidative membrane damage. Journal of Molecular Biology, 205, 1-16. https://doi.org/10.1007/ s00232-005-0753-8

Suwa, R., Hakata, H., Hara, H., El-Shemy, H. A., Adu-Gyamfi, J. J., Nguyen, N. T., \& Fujita, K. (2010). High temperature effects on photosynthate partitioning and sugar metabolism during ear expansion in maize (Zea mays L.) genotypes. Plant Physiology and Biochemistry, 48(2-3), 124-130. https://doi.org/10.1016/j. plaphy.2009.12.010

Tesfaye, K., Zaidi, P. H., Gbegbelegbe, S., Boeber, C., Getaneh, F., Seetharam, K., \& Stirling, C. (2017). Climate change impacts and potential benefits of heat-tolerant maize in South Asia. Theoretical and Applied Climatology, 130(3), 959-970. https://doi.org/10.1007/ s00704-016-1931-6

Tommasino, E., Griffa, S., Grunberg, K., Ribotta, A., Lopez Colomba, E., Carloni, E., \& Luna, C. M. (2012). Malondialdehyde content as a potential biochemical indicator of tolerant Cenchrus ciliaris L. genotypes under heat stress treatment. Grass and Forage Science, 67(3), 456-459. https://doi.org/10.1111/i.1365-2494.2012.00851.x

Waqas, M. A., Wang, X., Zafar, S. A., Noor, M. A., Hussain, H. A., Azher Nawaz, M., \& Farooq, M. (2021). Thermal stresses in maize: Effects and management strategies. Plants, 10(2), 293. https://doi. org/10.3390/plants10020293

Xiang, N., Hu, J., Wen, T., Brennan, M. A., Brennan, C. S., \& Guo, X. (2020). Effects of temperature stress on the accumulation of ascorbic acid and folates in sweet corn (Zea mays L.) seedlings. Journal of the Science of Food and Agriculture, 100(4), 1694-1701. https://doi. org/10.1002/jsfa.10184

Yadav, S. K., Tiwari, Y. K., Singh, V., Patil, A. A., Shanker, A. K., Lakshmi, N. J., \& Maheswari, M. (2018). Physiological and biochemical basis of extended and sudden heat stress tolerance in maize. Proceedings of the National Academy of Sciences, India Section B: Biological Sciences, 88(1), 249-263. https://doi.org/10.1007/s40011-016-0752-9

Yuzbasioglu, E., Dalyan, E., \& Akpınar, I. (2017). Changes in photosynthetic pigments, anthocyanin content and antioxidant enzyme activities of maize (Zea mays L.) seedlings under high temperature stress conditions. Trakya University Journal of Natural Sciences, 18(2), 97104. https://doi.org/10.23902/trkjnat.289527

Zafar, S. A., Hameed, A., Ashraf, M., Khan, A. S., Li, X., \& Siddique, K. H. (2020). Agronomic, physiological and molecular characterization of rice mutants revealed the key role of reactive oxygen species and catalase in high-temperature stress tolerance. Functional Plant Biology, 47(5), 440-453. https://doi.org/10.1071/FP19246

Zhu, X., Song, F., \& Xu, H. (2010). Influence of arbuscular mycorrhiza on lipid peroxidation and antioxidant enzyme activity of maize plants under temperature stress. Mycorrhiza, 20(5), 325-332. https://doi. org/10.1007/s00572-009-0285-7 